\title{
The effect of cross direction and ploidy level on phenotypic variation of reciprocal diploid and triploid mandarin hybrids
}

\author{
Dalel Ahmed ${ }^{1} \cdot$ Jean-Charles Evrard ${ }^{2} \cdot$ Patrick Ollitrault $^{2} \cdot$ Yann Froelicher $^{2}($ D \\ Received: 17 October 2019 / Revised: 7 January 2020 / Accepted: 14 January 2020 / Published online: 24 January 2020 \\ (C) The Author(s) 2020
}

\begin{abstract}
New citrus fruit varieties with the right pomological and organoleptic characteristics are expected by consumers and the fresh citrus fruit market. Apart from a good balance between sugar content and acidity, seedlessness is particularly demanded. Triploidy is one of the best ways to obtain seedless cultivars, and, taking advantage of diploid gametes, research programs have succeeded in creating them. Triploid hybrids are sterile and, when associated with parthenocarpy, produce seedless fruits. However, no studies have compared the potential agronomic interest of diploid and triploid cultivars to date. The aims of this study were to investigate the effects of (i) cross direction between diploid and triploid reciprocal populations of mandarin hybrids and (ii) the increase in ploidy level from diploidy to triploidy phenotypic variation in quantitative agronomic traits. Reciprocal crosses between 'Fortune' mandarin and 'Ellendale' tangor generated two diploid and two triploid populations; we then phenotyped by measuring fruit and juice weights, sugar content and titratable acidity over three harvesting campaigns. Significant differences in sugar and acidity levels were observed between triploid populations. Both triploid progenies varied according to their respective female genitor, unlike diploid populations in which no relationship was found between their phenotypic variation and that of their parents. Considering each cross direction separately, the comparison of diploid and triploid populations revealed that triploid hybrids were juicier and sweeter. A genomic dosage effect appears to be the most plausible explanation for these variations. These innovative results will help optimize triploid citrus breeding programmes by choosing the appropriate diploid gamete producing parent.
\end{abstract}

Keywords Ploidy $\cdot$ Mandarin $\cdot$ Reciprocal crosses $\cdot$ Dosage effect $\cdot$ Phenotypic variation

\section{Introduction}

Citrus are the most widely produced fruit in the world before watermelons and bananas (FAOSTAT 2019), with total estimated production of nearly 133 million tons in 2017, all species combined (FAOSTAT 2019). In the Mediterranean region, 25.2 million tons of citrus fruits were produced in 2016, including 6.9 million tons of mandarins (FAOSTAT

Communicated by W.-W. Guo

Electronic supplementary material The online version of this article (https://doi.org/10.1007/s11295-020-1417-7) contains supplementary material, which is available to authorized users.

Yann Froelicher

yann.froelicher@cirad.fr

1 UMR AGAP, INRA, CIRAD, Montpellier SupAgro, University of Montpellier, 20230 San Giuliano, France

2 CIRAD, UMR AGAP, 20230 San Giuliano, France
2017). To meet new market and consumer expectations, the creation of new varieties is indispensable (Goldenberg et al. 2018). Seedlessness is an essential characteristic for mandarins, and triploid breeding strategies have proved to be an efficient way of creating new citrus cultivars, particularly mandarins (Ollitrault et al. 2008; Navarro et al. 2015). Triploidy results in unbalanced meiosis leading to male and female sterility (Frost and Soost 1968) and hence to the production of seedless fruits when coupled with parthenocarpy (Ollitrault et al. 2008; Navarro et al. 2015). Three main type of crosses have been successfully applied to recover triploid citrus hybrids: $2 \mathrm{x} \times 4 \mathrm{x}$ and $4 \mathrm{x} \times 2 \mathrm{x}$ sexual hybridisation (Esen and Soost 1973a; Cameron and Burnett 1978; Starrantino and Recupero 1981; Ollitrault et al. 2008; Grosser and Gmitter 2011; Aleza et al. 2012a, 2012b; Navarro et al. 2015; Rouiss et al. 2017a, 2017b; Xie et al. 2015, 2019b) and 2x $\times 2 x$ sexual hybridisations (Esen and Soost 1971, 1973b; Ollitrault et al. 2008; Aleza et al. 2010b; Navarro et al. 2015; Cuenca et al. 2015a; Rouiss et al. 2017b; Handaji et al. 2018). In vitro 
embryo rescue and ploidy evaluation by flow cytometry were two decisive methods in developing efficient and extensive triploid breeding programmes from $2 \mathrm{x} \times 2 \mathrm{x}$ crosses (Ollitrault et al. 1996; Navarro et al. 2003; Aleza et al. 2010b).

The haploid number of chromosomes in citrus fruits and related genera is $9(2 \mathrm{n}=2 \mathrm{x}=18)$ (Krug 1943). Most Citrus are diploid but natural polyploids exist and have been identified, including the triploid 'Tahiti' lime (Citrus latifolia Tan.) and the tetraploid kumquat (Fortunella hindsii (Champ.) Swing.) (Ollitrault et al. 2003). Spontaneous tetraploids and triploids have also been found among the seedlings of diploid citrus cultivars and rootstock (Esen and Soost 1971, 1973b; Geraci et al. 1975; Ollitrault et al. 2008; Aleza et al. 2011).

Polyploidy results when some cell division mechanisms (mitosis) or gamete formation (meiosis) misfunction. Two types of polyploidisation thus exist: somatic polyploidisation and sexual polyploidisation. The first mechanism involves somatic cells whose mitosis is incomplete. The chromosomal stock that doubled during the cell division is contained in the only daughter cell produced (Carputo et al. 2003). The second mechanism, sexual polyploidisation, results from the nonreduction of gamete cells, also called diplogametes or $2 \mathrm{n}$ gametes. These originate from restitution of the meiotic cell cycle (Storme and Geelen 2013), which can take place during the first (FDR) or second (SDR) meiotic division (Bretagnolle and Thompson 1995; Gallais 2003; Cai and Xu 2007; Storme and Geelen 2013). Unreduced gametes are considered to be the main mechanism involved in plant ploidy evolution (Bretagnolle and Thompson 1995; Otto and Whitton 2000; Ramsey and Schemske 2002), and plant breeders took advantage of this type of gamete for crop improvement (Ramanna and Jacobsen 2003; Dewitte et al. 2012). Several polyploid cultivars resulted from meiotic restitution, including potato (Mendiburu and Peloquin 1971; Mok et al. 1975; Mendiburu and Peloquin 1977a, 1977b; Peloquin et al. 1989), lucerne (Bingham 1980; Veronesi et al. 1986), red clover (Smith et al. 1985), Vaccinium (Lyrene et al. 2003), Achillea borealis (Ramsey 2007), Ipomoea trifida (Iwanaga et al. 1991), Brassica spp. (Mason et al. 2011), Anthoxanthum alpinum (Bretagnolle 2001), Musa spp. (Ortiz 1997), Dactylis (Maceira et al. 1992), Rosa spp. (Zlesak 2009), maize (Rhoades and Dempsey 1966), Populus (Liesebach et al. 2015), Agave (Gomez et al. 2012) and Citrus (Frost et Soost 1968; Esen and Soost 1971; Geraci et al. 1975; Cuenca et al. 2015a; Rouiss et al. 2017a).

The $2 \mathrm{n}$ gamete frequency depends on the species, the genotype and on the environmental conditions (Barcaccia et al. 1997). In citrus, cytogenetic and molecular marker analyses (Esen and Soost 1971; Esen et al. 1979; Luro et al. 2004; Aleza et al. 2015; Cuenca et al. 2015a) showed that sexual polyploidisation occurs mainly through the formation of the female diplogamete at frequencies ranging from less than $1 \%$ to more than 20\% (Soost 1987, Iwamasa et al. 1988; Esen and
Soost 1971; Ollitrault et al. 2008; Cuenca et al. 2015a). SDR has been described as the main mechanism involved in the formation of the $2 \mathrm{n}$ ovule in 'Nules' clementine (Luro et al. 2004; Aleza et al. 2015) and in a wide range of mandarins (including 'Fortune' mandarin), tangor (including 'Nadorcott' tangor) and tangelos (Xie et al. 2014; Cuenca et al. 2011, 2015a). In addition to SDR, FDR and postmeiotic restitution were observed in lemon megagametophytes (Xie et al. 2019a; Rouiss et al. 2017a). 2n male gametes have also been described in a few studies. After analysing triploid hybrids with clementine as female parent, Luro et al. (2004) concluded that $2 \%$ arose from $2 \mathrm{n}$ pollen. More recently, single-pollen genotyping studies (Honsho et al. 2012, 2016) demonstrated the formation of $2 \mathrm{n}$ pollen gametes through FDR mechanism in 'Nishiuchi Konatsu' mandarin (Citrus tamurana Hort. Ex Tanaka), even though the recovery of the plants failed. In $4 \mathrm{x} \times$ $2 \mathrm{x}$ sexual hybridisation trials, Rouiss et al. (2017a) used the 'CSO' diploid tangor as pollinator of two doubled-diploids, 'Moncada' mandarin and 'Fina' clementine. Molecular analyses showed that the resulting tetraploid hybrids were the result of $2 \mathrm{n}$ pollen, $89 \%$ of which resulted from the FDR mechanism. For lemon, Xie et al. (2019a) proposed that the $2 \mathrm{n}$ pollen might be the result of the formation of parallel spindles at meiosis stage II.

In the last 20 years, several breeding programmes have extensively exploited $2 \mathrm{n}$ gametes in developing new seedless citrus varieties for commercial purposes (Ollitrault et al. 1996, 2008; Navarro et al. 2003; Aleza et al. 2010b; Navarro et al. 2015; Handaji et al. 2018). As part of a Spanish breeding programme at IVIA, Aleza et al. (2010b) recovered very large triploid progenies from $2 \mathrm{x} \times 2 \mathrm{x}$ hybridisations using numerous self-incompatible and monoembryonic genotypes as female parents. These authors demonstrated that the frequency of unreduced gametes depends on the maternal genotype and that Fortune mandarin displayed the highest $2 \mathrm{n}$ gamete frequency. Aleza et al. (2010a) thus obtained the triploid 'Garbi' mandarin using the diploids Fortune mandarin and tangor 'Murcott' (Citrus reticulata $\times$ Citrus sinensis), and Cuenca et al. (2010) recovered the triploid 'Safor' mandarin from the two diploid mandarins Fortune and 'Kara' (Citrus unshiu $\times$ Citrus nobilis). Both the resulting seedless triploid hybrids, which are now cultivated, are of high quality and ripen in the late and mid-season respectively. A cross between Fortune and Kara mandarins produced another new cultivar, 'Albir' triploid mandarin (Cuenca et al. 2015b), which matures 1 month earlier than Safor mandarin. Another triploid citrus breeding programme was carried out in Morocco, where the clementine 'Sidi Aissa' was used as the female parent in two crosses (Handaji et al. 2018). The first hybridisation was performed using the pollen of 'Osceola' mandarin and generated the new 'Aya' cultivar. The second hybridisation produced the new 'Hana' mandarin using the pollen of 'Wilking' mandarin. The two new seedless cultivars have 
been evaluated at the pomological and organoleptic levels and displayed interesting characteristics particularly related to peeling, juiciness and taste (Handaji et al. 2018).

Consumers are increasingly demanding the quality of citrus fruit they would like to find on the market. Their perception of the fruits is governed by a set of characteristics which are not only visual but include taste and sensory perception. Thus, in addition to seedlessness, consumers will pay particular attention to the colour of the peel and pulp, which are both controlled by carotenoid and apocarotenoid content and composition (Froelicher et al. 2011; Garcia-Lor et al. 2015; Alquezar et al. 2008). Indeed, mandarins are characterized by a complex composition of carotenoids which results in their orange to reddish colour (Spiegel-Roy and Goldschmidt 1996; Alquezar et al. 2008). Anthocyanin pigments are targeted by breeding programmes who wish to develop blood-mandarin varieties. By performing crosses between varieties of mandarin and blood oranges, researchers succeeded in producing new triploid mandarin hybrids such as 'Tacle' and 'Sweet Sicily' mandarins (Rapisarda et al. 2008; Russo et al. 2015). The shape and size of the fruit are also part of the visual appreciation. Mandarins vary in shape between oblate, subglobose to oblate-necked (Goldenberg et al. 2018). The diameter of most mandarins ranges between 50 and $80 \mathrm{~mm}$ (Abouzari and Nezhad 2016). The European marketing regulation (EU 2017) requires a minimum diameter of $45 \mathrm{~mm}$ for mandarin varieties and their hybrids. Easy peeling is another desired characteristic which facilitates mandarin consumption. Compared to oranges, mandarins can be considered as easy to peel, even though the albedo of some varieties is difficult to separate from the pulp (Goldenberg et al. 2014). The perception of citrus fruit taste is mainly related to sugar content and acidity level. These two parameters vary considerably among mandarins, as demonstrated by Goldenberg et al. (2014) where the diversity panel ranked acidity between 0.5 and $2 \%$, and sugar content between 9.6 and $15.5 \%$. The sugar/ acidity ratio is the maturity index, which is extensively used as an indicator to choose the appropriate harvest date. The minimum ratio accepted by the European mandarin market is 7.5 (EU 2017). According to Goldenberg et al. (2015), the mandarins that are most appreciated by the largest number of consumers contain an average of $13.1 \%$ sugar content, $1.1 \%$ acidity and a maturity index of 13.2. Although these are generally the main indicators of the sensory quality of citrus fruits, aroma volatiles and fruit texture (Goff and Klee 2006; Tietel et al. 2011; Goldenberg et al. 2015) are equally decisive. It has been shown that different volatile compounds contribute to mandarin flavour (Schieberle et al. 2003; Miyazaki et al. 2012) and that each combination is characteristic of a mandarin sub-group (Goldenberg et al. 2015). Texture includes juiciness, chewiness and gumminess (Tietel et al. 2011). Juiciness (percentage juice) is widely preferred in mandarins (Goldenberg et al. 2015, 2018), and its minimum must be
$33 \%$ to comply with European mandarin marketing standards (EU 2017). Furthermore, the mouth-feel sensation plays a key role in perception of the fruit as gumminess negatively affects sensory appreciation (Goldenberg et al. 2015).

The quality of citrus fruit is determined by a combination of several elements, which, when they are at optimal level, meet the needs of the market and satisfy the largest number of consumers. A better understanding of the phenotypic behaviour of polyploid hybrids is required to profit from advances in plant breeding programmes.

The INRA-Cirad research centre in San-Giuliano, Corsica, has a plant breeding programme dedicated to triploid citrus hybrids. The main aim of the selection programme is to produce high-quality, late-maturing, seedless mandarins. Numerous progenies, mainly triploid but also diploid mandarins, were recovered through two $2 \mathrm{x} \times 2 \mathrm{x}$ sexual hybridisations, using the diploid parents Fortune mandarin and 'Ellendale' tangor. The genitors, which share very close or similar cytotypes (Froelicher et al. 2011; Garcia-Lor et al. 2015), were each used as female and male parent reciprocally, generating two distinct populations (ForEl and ElFor), each with two ploidy levels (diploid and triploid). The recovered triploid hybrids, which resulted from $2 \mathrm{n}$ eggs, were planted in the field in 2006, the diploid ones in 2011. In the present work, we focused on three harvesting campaigns (2015-2016, 2016-2017 and 2017-2018) and analysed four main quantitative traits in both triploid and diploid hybrid fruits on (fruit weight, juice weight, acidity and sugar content) and two derived characteristics (juice percentage and $\mathrm{E} / \mathrm{A}$ ratio). Using statistical analyses, we investigated (i) the cross direction effect on phenotypic variation in triploid hybrids, in which the potential effect of the allelic dosage is mixed with the maternal effect; (ii) the cross direction effect in diploids, in which only the maternal effect is hypothesised and (iii) the effect of the ploidy level by comparing variations in the phenotypic data of triploid and diploid hybrid fruits, each population (ForEl and ElFor) being examined independently. We discuss the probable causes of the observed variation and the advantages of producing triploid mandarins.

\section{Materials and methods}

\section{Plant material}

A total of 108 triploid and 25 diploid hybrids were obtained from two crosses between Fortune mandarin (Citrus clementina $\times$ Citrus reticulata) and Ellendale tangor (Citrus reticulata Blanco $\times$ Citrus sinensis (L.) Osb.), used as both female and male diploid genitors. Both were chosen for their fruit quality, late production and sexual characteristics. They are monoembryonic, self-incompatible and have hermaphrodite flowers which enable reciprocal crosses. Embryo rescue 
and flow cytometry were performed to separate the triploid from the diploid seedlings, as described in Aleza et al. (2010b). Fortune mandarin was considered as a hybrid between the clementine and the 'Dancy' mandarin (Furr 1964; Hodgson 1967) which is characterized by late maturity. However, molecular studies rejected this origin and suggested that Fortune probably resulted from a cross between clementine and 'Orlando' tangelo (itself a clementine and Dancy mandarin hybrid) (Barry et al. 2015). In Corsica, Fortune fruits are harvested between the end of February and April. They are appreciated for their organoleptic qualities, especially slight acidity and a good balance between sugar and acidity. Its fruits are of medium size, characterized by easily peeled thin skin and few seeds. The Ellendale tangor is assumed to be a spontaneous hybrid between a mandarin and an orange. It also matures late and is harvested between late February and late April in Corsica. It is large, its fruits enable outstanding conservation but the skin adheres, which complicates peeling.

The generated triploid hybrids were planted in 2006 at the San-Giuliano research site in Corsica, while the diploid hybrids were planted in 2011. The two planting plots are flat, geographically close and have the same physical and chemical characteristics. To satisfy the first step of the varietal selection process, hybrids were phenotyped by measuring four main criteria: average fruit weight, average juice weight, acidity and sugar content; plus two derived criteria: juice percentage and E/A ratio. The plants were phenotyped over three harvest campaigns (2015-2016, 2016-2017 and 2017-2018). In the following, ForEl refers to the hybrids resulting from the Fortune mandarin $x$ Ellendale tangor cross, and ElFor refers to the hybrids resulting from the Ellendale tangor $\times$ Fortune mandarin cross. In total, there were 84 triploid ForEls, 24 triploid ElFors, 10 diploid ForEls and 15 diploid ElFors.

\section{Plant measurements}

According to the protocol set up at the INRA-Cirad station in San-Giuliano, triploid hybrids are mostly phenotyped between January and March, but phenotyping can extend until May. Phenotyping of diploids generally starts in December and continues until March. This shift in harvest periods is because polyploid genotypes mature later than diploid ones, as first reported by Stebbins (1947). For analysis, five fruits were randomly collected all around one tree of each genotype at 15-day intervals. All the fruits were weighted and the average weight calculated. The juice of all five fruits was extracted using an electric juicer. The resulting juice was weighed and the average juice weight per fruit computed. The juice percentage was the ratio between the weight of the juice and the weight of the fruits. Sugar content ( ${ }^{\circ}$ Brix), also, called total soluble solids
(TSS), was measured with a refractometer. Titratable acidity was determined by titrating $1 \mathrm{~g}$ of juice with $0.1 \mathrm{~N}$ of $\mathrm{NaOH}$ and is expressed in grams of citric acid per $100 \mathrm{~g}$ of juice or as a \%. The coefficient of maturity E/A corresponding to the ratio of sugar to acidity was also evaluated for each hybrid.

Changes in each of these traits over the phenotyping period were evaluated using average values computed, each time, according to the population (ForEl, ElFor), the ploidy level, the sampling month (December-March for diploids, JanuaryMarch for triploids) and the year of the campaign. To analyse the effects of cross direction on triploid and diploid ForEl and ElFor hybrids as well as the impact of the ploidy level within each population, each hybrid was represented by a single mean value calculated from all its sampled values regardless of the harvesting month. The same calculation was applied to the sampled parents' data.

\section{Statistical analyses}

All statistical analyses were performed with RStudio software. Normality and homoscedasticity tests of the residues were applied to the variables using the Shapiro-Wilk and Bartlett tests, respectively. When the conditions for applying the analysis of variance (ANOVA) were not met, the data were transformed. The ANOVA test was applied to evaluate the effect of cross direction on phenotypic variation, according to the following model:

$Y i j=\mu+\alpha i+\beta \mathrm{j}+\theta \mathrm{ij}+\varepsilon i j ;$

where

$Y_{i j}$ phenotypic value of the cross $i$ of the year $j$

$\mu$ average value

$\alpha_{i} \quad$ cross direction i effect

$\beta_{j} \quad$ sampling campaign $\mathrm{j}$ effect

$\theta \mathrm{ij}$ interaction between the cross direction i effect and the sampling campaign $\mathrm{j}$ effect

$\epsilon_{\mathrm{ij}} \quad$ residual error effect

All the effects were fixed except residual error. A significance threshold of 0.05 was set for all the tests performed. This ANOVA model was used to separately analyse triploid and diploid hybrids. Principal component analysis (PCA) was performed using the $\{$ FactoMineR $\}$ (Husson et al. 2016) and \{factoextra\} (Kassambara and Mundt 2017) R packages. Hierarchical clustering and heat-map analyses were performed with the \{gplots\} (Warnes et al. 2016) R package. The effect of the ploidy level on phenotypic variation within ForEl and ElFor populations was examined by comparing means using $t$ tests. 


\section{Results}

\section{Kinetics of the quantitative traits over the phenotyping period}

We first studied the variability of the unprocessed traits (average fruit weight, average juice weight, titratable acidity and sugar content) over the course of the sampling months.

For triploid hybrids (Supplemental Fig. 1 and Supplemental Table 1 in the Supporting Information), the average fruit weight of ElFor hybrids harvested in 2016-2017 and of ForEl hybrids in 2017-2018 displayed increasing curves. The changes observed in the remaining hybrids were quite different, as data from ForEl hybrids sampled in February showed a slight decrease compared with data sampled in January in 2015-2016 and 2016-2017 and with ElFor in 2015-2016. Nevertheless, the fruit weights recorded at the end of the harvest campaign were still higher than at the beginning. Kinetics of the average weights of juice were more variable. While ForEl hybrids sampled in 2016-2017 and 2017-2018 and ElFor fruits sampled in 2016-2017 showed an increasing trend, the other samplings displayed decreasing trends. However, the differences in fruit weights recorded for ForEl and ElFor harvested in 2015-2016 appeared to diminish for juice weights. Except for ForEl in 2017-2018, sugar content across the harvest dates increased between January and February but remained stable between February and March. All the hybrids showed decreasing trends in titratable acidity, except hybrids in the 2016-2017 campaign for which no variability was observed.

The pattern of change over the course of the harvesting dates of the diploid hybrids (Supplemental Fig. 2 and Supplemental Table 2 in the Supporting Information) displayed much more variability especially the average fruit and juice weights. The curves of the diploid ForEl fruit and juice weights decreased while those of the diploid ElFor either increased or remained stable. Overall, sugar content increased and titratable acidity decreased, as expected.

\section{Reciprocal hybrids and phenotypic variation}

\section{Effect of cross direction on triploid populations}

We compared the variability of the six studied traits between ForEl and ElFor triploid hybrid populations, performed boxplots (Fig. 1) and supported our results using statistical tests (Table 1). Regarding the average fruit weight, comparison of boxplot medians showed that triploid ElFor hybrids were slightly heavier than ForEl hybrids in 2015-2016 and 2017-2018, whereas the opposite was the case in the 20162017 campaign. The same pattern was observed in juice weight. However, the significance tests of the impact of cross direction on either the average weight of fruit or on the juice weight were inconclusive $(p$ values $=0.06877$ and 0.2516 respectively). Only two characters out of six were significantly affected by the cross direction. Triploid ForEl hybrids displayed higher sugar contents than triploid ElFor hybrids $\left(p\right.$ value $\left.=1.531 \mathrm{e}^{-08 * * *}\right)$ and higher acidity $(p$ value $=$ $\left.0.0195375^{*}\right)$. Interestingly, depending on the variety used as female parent, the differences between the average offspring results matched the relative value of the two parents. For example, ElFor hybrids had heavier fruits than ForEl hybrids (Fig. 1a) and the female parent Ellendale tangor was heavier than the male parent Fortune mandarin. The harvesting campaign had a significant effect on the phenotypic variation of all the studied traits (Supplemental Table 1 in the Supporting Information), except the juice percentage, which remained stable over the 3 years (Fig. 1f). These results agree with those of the PCA analysis (Supplemental Fig. 3 in the Supporting Information). The two first axes accounted for $80.2 \%$ of total variance. The first component (Dim 1) was highly correlated with average fruit weight, and to a lesser extent with average juice weight (Supplemental Fig. $3 \mathrm{~b}$ in the Supporting Information). The second component (Dim 2) was correlated with acidity level and sugar content (Supplemental Fig. 3b in the Supporting Information). Focusing first on ForEl populations over the three campaigns (Supplemental Fig. 3a in the Supporting Information), the populations differed significantly in their coordinates on Diml but only the hybrids in 2015 2016 differed slightly from the two other campaigns according to Dim2. As was the case with boxplots, this shows that the ForEl fruits in the 2015-2016 campaign contained more juice, were heavier, less acidic and less sweet than those harvested in 2016-2017 and 2017-2018. The same pattern was observed for the ElFor hybrids, with even a greater difference between campaigns according to Dim 2. The PCA again demonstrated that overall, ElFor hybrids had heavier fruits and a greater juice weight, and ForEl hybrids had more acidic and sweeter fruits (Supplemental Fig. 3 in the Supporting Information). In addition, these results agree with what we observed for the parents. Fortune mandarin values were negatively correlated with Dim 1 and positively correlated with Dim 2, whereas, despite greater dispersion among years, Ellendale tangor showed the reverse pattern. These results demonstrate that, as was the case for ForEl hybrids compared with ElFor hybrids, Fortune mandarin has smaller fruits with higher citric acid and sugar contents than Ellendale tangor.

Hierarchical clustering and heat-map analyses were conducted on ForEl and ElFor hybrids in each harvesting campaign, based on four of the six quantitative trait (the average weight of one fruit, the average weight of its juice, acidity level and sugar content). Transformed characters (juice percentage and $\mathrm{E} / \mathrm{A}$ equilibrium) were excluded to avoid dispersed plot points and redundant information. Examination of the 2015-2016 campaign data (Fig. 2) showed the variables were clustered in two groups: acidity and sugar contents in one and fruit and juice weights in the 
Fig. 1 Boxplots of the distribution of six quantitative traits per triploid population (ForEl, ElFor) and per campaign (2015-2016, 2016-2017 and 2017-2018). a Average fruit weight. b Average juice weight. c Sugar content. d Titratable acidity. e E/A ratio. f Juice percentage. Red dots refer to the 'Fortune' mandarin values and orange dots to the 'Ellendale' tangor ones
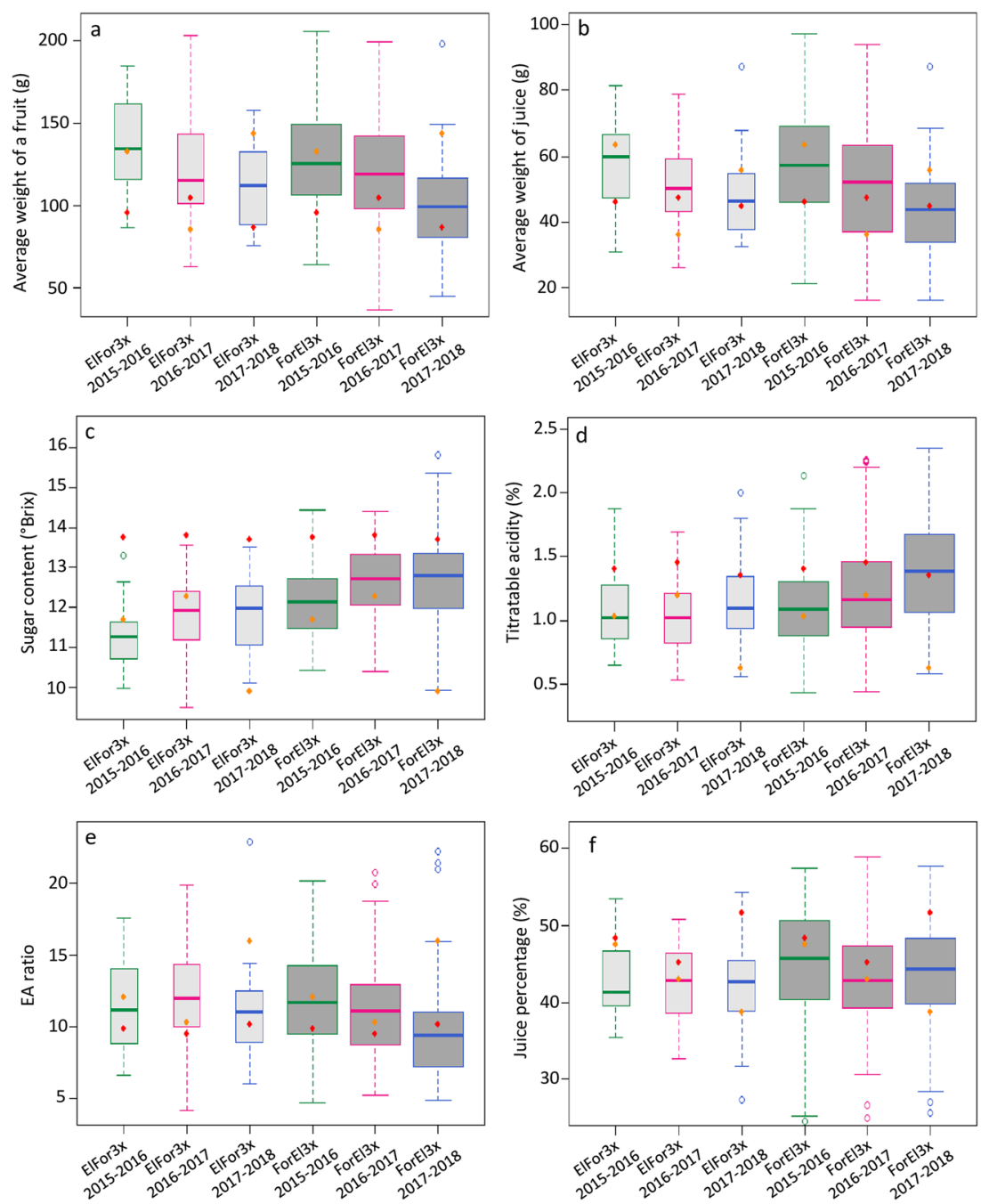

other. The triploid ForEl and ElFor hybrids were divided into three main clusters. Cluster I (from the bottom to the top) included $37.5 \%$ of the ElFor hybrids and $21.43 \%$ of the ForEl hybrids and grouped heavy fruits with high juice weight and low sugar and acidity contents. Ellendale tangor was in cluster II, which included $45.83 \%$ of ElFor fruits and $29.76 \%$ of ForEl hybrids. Cluster II grouped light weight fruits with low juice weight and low titratable acidity and sugar levels. Cluster III contained Fortune mandarin and grouped hybrids with light weight fruits and low juice weight. It was divided into two sub-clusters, the first grouped acidic fruits (16.67\% of ElFor and $14.29 \%$ of ForEl), and the second grouped fruits with high sugar content and contained only ForEl hybrids (34.52\% of the total ForEl). Although hierarchical clustering of the 2016-2017 data (Supplemental Fig. 4 in the Supporting Information) appears to be less precise than the one described above and the one obtained with the 2017-2018 data (Supplemental Fig. 5 in the Supporting Information), overall phenotypic data were consistent from 1 year to another, subdividing the hybrids according to their weight, sugar and acidity levels.

\section{Cross direction effect on diploid populations}

The same analyses were conducted on data from diploid ForEl and ElFor hybrids (Fig. 3; Table 2). In comparison with triploid hybrids, neither sugar nor acidity content differed significantly between diploid ForEl and ElFor hybrids, but juice weight $(p$ value $\left.=0.003077^{*}\right)$, juice percentage $(p$ value $=$ $\left.0.0002066^{* * *}\right)$ and the $\mathrm{E} / \mathrm{A}$ ratio $\left(p\right.$ value $\left.=0.046704^{*}\right)$ did. Diploid ElFor fruits had significantly higher juice weight and juice percentage and a lower E/A ratio than ForEl hybrids. Data on fruit weight, sugar contents and acidity levels in the two populations were close. Unlike our observations of triploid populations, the phenotypic variability of hybrids according to the genitors' values did not follow the same pattern, so no relation was observed between the changes in both hybrids and parents. A significant variation between harvesting campaigns was observed in three out of the six phenotypes studied: titratable acidity, juice percentage and the E/A ratio (Table 2).

The two first axes of the PCA (Supplemental Fig. 6 in the Supporting Information) accounted for $73 \%$ of the total 
Table 1 Analysis of variance (ANOVA) of the triploid quantitative data. Characters in italics indicate a significant effect at the $5 \%$ level. Cross direction $\times$ campaign interactions were tested and none was significant at the $5 \%$ level

\begin{tabular}{llllrl}
\hline Variable & Transformation & Effect & d.f. & F-value & $p$ value \\
\hline Average fruit weight & $\log _{10}$ & Cross & 1 & 3.3348 & 0.06877 \\
& & Campaign & 2 & 17.1774 & $8.243 e^{-08 * * *}$ \\
Average juice weight & $\log _{10}$ & Cross & 1 & 1.3193 & 0.2516 \\
& & Campaign & 2 & 17.2628 & $7.631 e^{-08 * * *}$ \\
Sugar content & \multirow{2}{*}{ None } & Cross & 1 & 33.7362 & $1.531 e^{-08 * * *}$ \\
& & Campaign & 2 & 8.2123 & $0.0003331 * * *$ \\
Titratable acidity & $\log _{10}$ & Cross & 1 & 5.5085 & $0.0195375 *$ \\
& & Campaign & 2 & 7.2773 & $0.0008122 * * *$ \\
Juice percentage & $\log _{10}$ & Cross & 1 & 0.4321 & 0.5114 \\
& & Campaign & 2 & 0.7991 & 0.4506 \\
E/A ratio & \multirow{2}{*}{$\log (\mathrm{var}+1)$} & Cross & 1 & 1.3789 & 0.2411703 \\
& & Campaign & 2 & 8.0346 & $0.0003944 * * *$ \\
\hline
\end{tabular}

variance. Like the triploid populations, the first component (Dim 1) was highly correlated with the average fruit weight and the average juice weight (Supplemental Fig. 6b). However, the second component (Dim 2) was positively correlated with the acidity level and negatively correlated with the sugar content. The distribution of ForEl and ElFor diploid hybrids was mixed compared to the one of the triploid hybrids (Supplemental Fig. 6a). The phenotypic data collected in 2015-2016 were characterized by relatively high fruit and juice weights, lower acidity and slightly higher sugar contents in both populations compared to the other harvesting campaigns. According to Dim 1, the difference between ForEl and ElFor hybrids collected in 2016-2017 and 2017-2018 was much less pronounced than in the triploid populations, and highlighted higher fruit and juice weights in ElFor hybrids. The populations differed slightly according to Dim 2, with more acidic and less sweet fruits for ElFor hybrids than ForEl ones. These results agree with the previous analyses.

Hierarchical clustering and heat-map analyses were also conducted on data collected from the diploid ForEl and ElFor during the three campaigns (Fig. 4). Like the triploid populations, the average fruit and juice weights were clustered together on the one hand and acidity and sugar content on the other. The ForEl and ElFor hybrids were divided into three clusters, and all the Fortune samples made a fourth cluster. Cluster I (from bottom to top) grouped heavy fruits with high rates of juice but low titratable acidity and sugar contents. Cluster I comprised $26.67 \%$ of ForEl, $33.33 \%$ of ElFor and Ellendale data collected in 2015-2016 and 2017-2018. Cluster II comprised $13.33 \%$ of ForEl and $15.56 \%$ of ElFor, whose fruits were characterized by high titratable acidity, low sugar content and low fruit and juice weights. These fruits would be of little agronomic interest. Cluster III grouped hybrids with light fruit and juice weights. It was divided into four sub-clusters. The first one (from bottom to top) grouped fruits with very low acidity and low sugar content (13.33\% of ForEl and $15.56 \%$ of ElFor). The second grouped fruits also with low acidity but high sugar contents $(16.67 \%$ of ForEl, $11.11 \%$ of
ElFor and Ellendale data of 2016-2017). The third contained fruits with low acidic levels and sweet fruits (20\% of ForEl and $6.67 \%$ of ElFor). The fourth sub-cluster grouped acidic fruits with low sugar content (10\% of ForEl and $17.78 \%$ of ElFor). These fruits would also be of little agronomic interest as small sour fruits are rarely appreciated. It was interesting to observe that three hybrids were grouped in the same cluster irrespective of the harvest year: one ElFor (B4) and one Forel (E7) were grouped in cluster I and one Elfor hybrid (B5) in cluster II.

\section{Effect of ploidy level on phenotypic variation}

To analyse the data collected between January and March, a period when data were available for both populations, we performed $t$ tests on ForEl and ElFor hybrids separately to evaluate the effect of the ploidy level on variations in quantitative traits (Fig. 5; Supplemental Table 3 in the Supporting Information). Although differences in the average weight of fruit between diploid and triploid ForEl populations were visible, triploid fruits being heavier, the $t$ test was not significant for any harvest campaign, whereas the test was significant between diploid and triploid ElFor populations in the 20162017 campaign ( $p$ value $=0.03462$ ). Juice weight was significantly higher in triploid ForEl hybrids than in diploid hybrids in 2015-2016 campaign ( $p$ value $=0.01799$ ) and in the 20161017 campaign ( $p$ value $=0.001244$ ). That was also the case of the ElFor populations in the same harvesting campaigns ( $p$ values 0.03081 and 0.01399 respectively). The ploidy level had a positive significant effect on sugar content in both ForEl (in all harvest years) and in the ElFor 2016-2017 and 20172018 populations. Very few variations in titratable acidity were observed between diploid and triploid hybrid populations, except in the 2015-2016 campaign in which triploid ForEl hybrids had significantly higher acidic levels than diploid ones. The juice percentage was significantly higher in triploid ForEl in all the campaigns, but was significantly higher in diploid ElFor ( $p$ value $=0.00936$ ) only in $2017-$ 

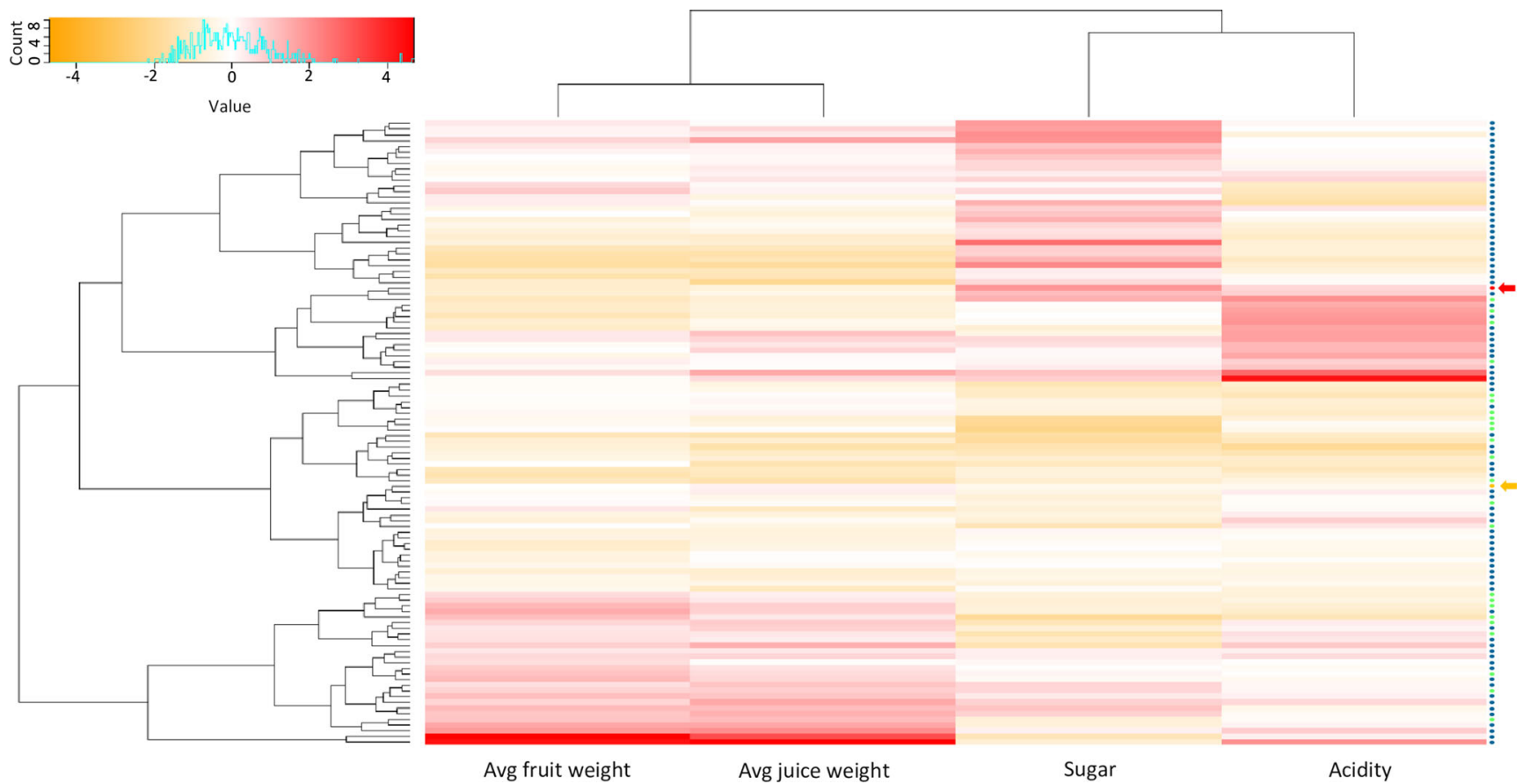

Fig. 2 Hierarchical clustering of triploid ForEl and ElFor hybrids and heat-map analysis of the main variables (average fruit weight, average juice weight, sugar content and titratable acidity) for the 2015-2016

campaign. Blue dots refer to ForEl hybrids, and green dots to ElFor ones. The red arrow indicates the Fortune mandarin parent and orange arrow the Ellendale tangor parent

2018. The E/A ratio between diploid and triploid populations differed significantly only in ElFor populations, in which triploid hybrids had higher ratios than diploid hybrids in the 2016-2017 campaign ( $p$ value $=0.01077$ ). More generally, even if not all the statistical tests applied were significant, triploid ForEl fruits were on average $11.6 \%$ heavier, $30.85 \%$ juicer, $10.75 \%$ sweeter and $8.77 \%$ more acidic than diploid ones, while triploid ElFor fruits were $14.68 \%$ heavier, $14.84 \%$ juicer, $6.71 \%$ sweeter and $5.4 \%$ less acidic than Diploid Elfor.

\section{Discussion}

\section{Kinetics of the sugar content and acidity level during the phenotyping period}

We studied the kinetics of four quality parameters, fruit weight, juice weight, acidity level and sugar content. We observed that the average weights of fruit generally tended to increase over the course of the harvest period especially in triploid hybrids. Variable patterns were also observed in the average juice weights in both diploids and triploids. These unexpected variations could be explained by heterogeneity within the same genotype caused by physiological factors. As sampling was randomly conducted all around each tree, especially to represent the variability due to exposure to solar radiation, the size of fruits and therefore their fruit and juice weights varied over the course of the harvesting period. We also noted a general increase in sugar contents while acidity

level decreased over the course of the harvesting period in both diploid and triploid hybrids. These results are consistent with those of previous studies (Bartholomew and Sinclair 1943; Blumwald 2007; Lado et al. 2014) demonstrating that citrus fruits accumulate sugars and degrade acidity during ripening. Sucrose is the main type of sugar in citrus. The gene encoding the enzyme responsible for sucrose synthesis is induced during fruit ripening and contributes to its transport to the vacuoles (Castellarin et al. 2011). Conversely, citric acid, which is the main acid in citrus species, is translocated from the vacuoles of the juice sacs to the peel tissue, where it is metabolized (Murata 1977; Echeverria and Valich 1988).

\section{The effect of cross direction on phenotypic variation}

We examined the phenotypic variation in six quantitative characters (fruit weight, juice weight, acidity level, sugar content, juice percentage and E/A ratio) between ForEl and ElFor populations, considering each ploidy level separately. The aim was to observe how hybrid populations behave depending on whether the female parent was Fortune mandarin or Ellendale tangor. Triploid ForEl hybrids contained significantly larger amounts of sugar and a higher acidity level than triploid ElFor hybrids. Interestingly, Fortune had higher acid and sugar contents than Ellendale. Therefore, at triploid level, there appears to be a maternal effect on sugar and acid content. Considering that as demonstrated by Cuenca et al. (2015a), in mandarins and tangors, most of the triploid hybrids obtained through $2 \mathrm{x} \times 2 \mathrm{x}$ hybridisation result from $2 \mathrm{n}$ ovules; this maternal effect could 
Fig. 3 Boxplots of the distribution of six quantitative traits per diploid population (ForEl, ElFor) and per campaign (2015-2016, 2016-2017 and 2017-2018). a Average fruit weight. b Average juice weight. c Sugar content. d Titratable acidity. e E/A ratio. f Juice percentage. Red dots refer to the Fortune mandarin values and orange dots to the Ellendale tangor ones
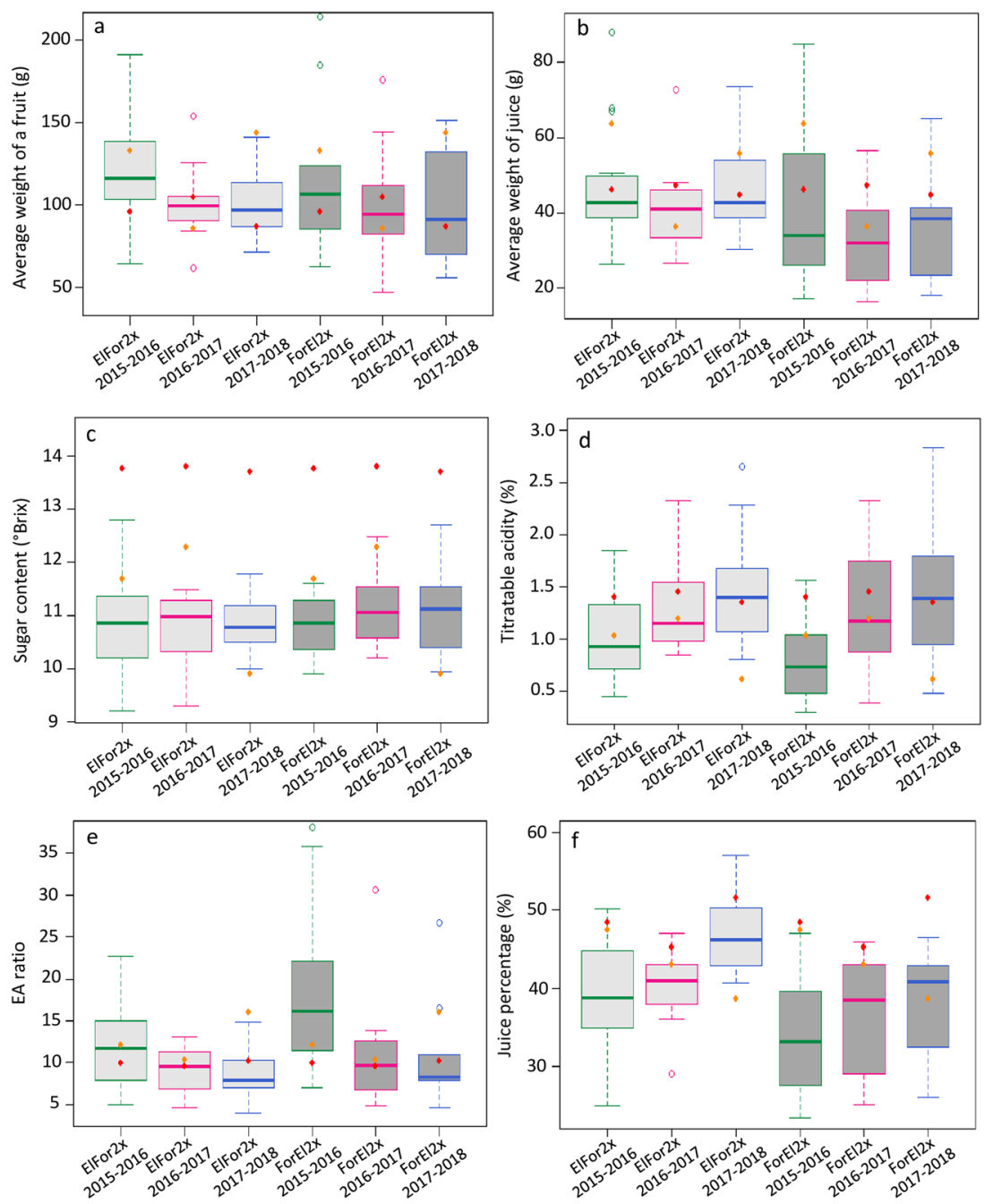

be explained by three main hypotheses (i) a parental allele dosage effect, (ii) a cytoplasmic genome (mitochondria and chloroplast) effect or (iii) maternal imprinting. Imprinting is an epigenetic phenomenon leading to parent-of-origin-specific differential expression of maternally and paternally inherited alleles. However, only a few imprinted genes have been described in plants, and they were involved in endosperm development and in the inhibition of interspecific hybridisation (Ohnishi et al. 2014; Liu et al. 2018). In citrus, both the chloroplast and mitochondria are maternally inherited. Under the hypothesis of cytoplasmic genome
Table 2 Analysis of variance (ANOVA) of the diploid quantitative data. Characters in italics indicate a significant effect at the $5 \%$ level. Cross direction $\times$ campaign interactions were tested and none was significant at the $5 \%$ level

\begin{tabular}{llllll}
\hline Variable & Transformation & Effect & d.f. & F-value & $p$ value \\
\hline Average fruit weight & \multirow{2}{*}{$\log _{10}$} & Cross & 1 & 0.8641 & 0.35583 \\
& & Campaign & 2 & 2.8233 & 0.06629 \\
Average juice weight & \multirow{2}{*}{$\log ($ var +1$)$} & Cross & 1 & 9.4136 & $0.003077 * *$ \\
& & Campaign & 2 & 1.0656 & 0.350125 \\
Sugar content & \multirow{2}{*}{ None } & Cross & 1 & 1.9462 & 0.1675 \\
Titratable acidity & \multirow{2}{*}{ None } & Campaign & 2 & 0.1604 & 0.8521 \\
& & Cross & 1 & 0.4297 & 0.514316 \\
Juice percentage & \multirow{2}{*}{ None } & Campaign & 2 & 7.1297 & $0.001532 * *$ \\
& & Cross & 1 & 15.3607 & $0.0002066 * * *$ \\
E/A ratio & \multirow{2}{*}{ Log $($ var +1$)$} & Campaign & 2 & 7.1604 & $0.0014938 * *$ \\
& & Cross & 1 & 4.1019 & $0.046704 *$ \\
& & Campaign & 2 & 6.6997 & $0.002192 * *$ \\
\hline
\end{tabular}



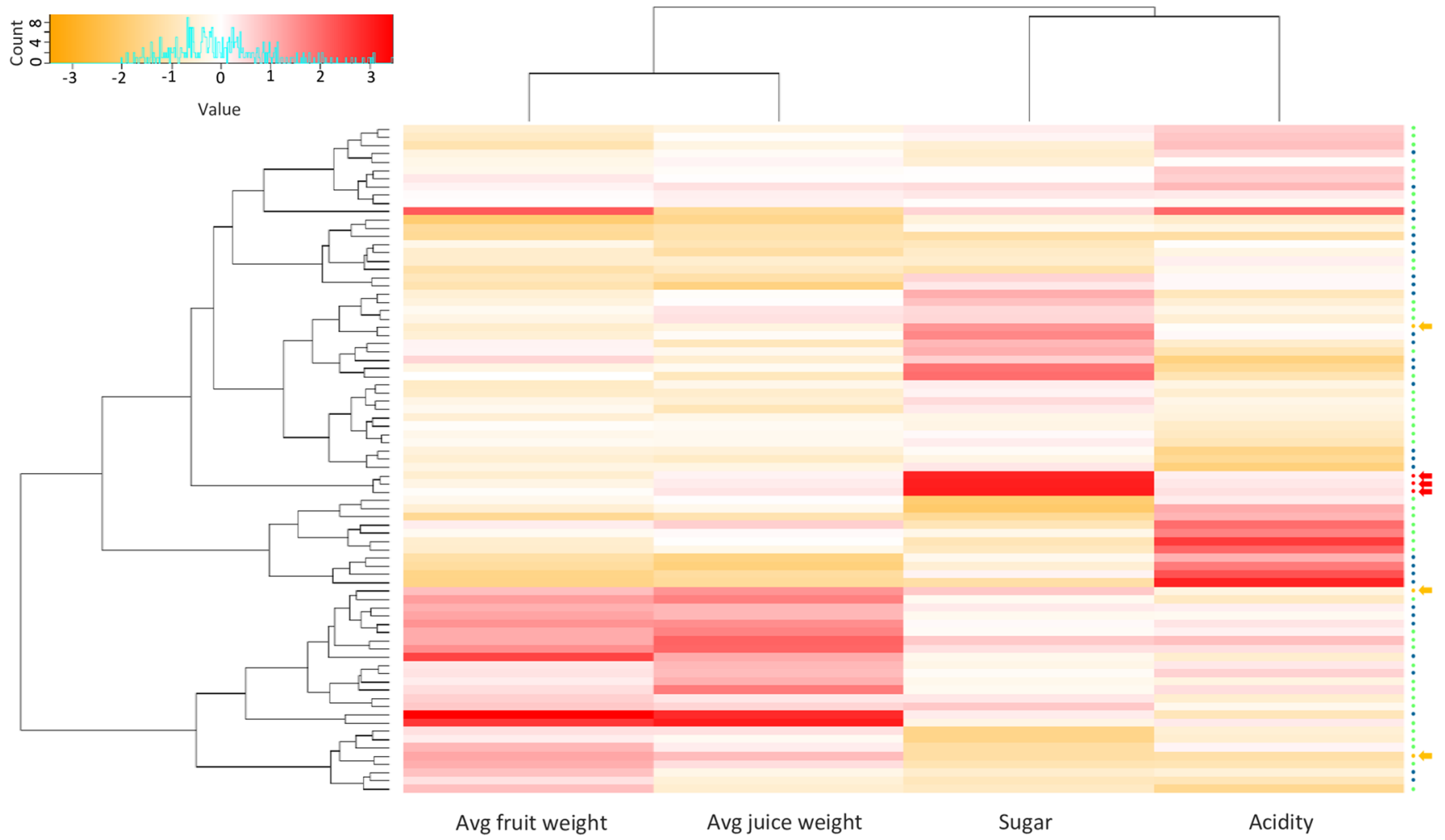

Fig. 4 Hierarchical clustering of diploid ForEl and ElFor hybrids and heat-map analysis of the main variables (average fruit weight, average juice weight, sugar content and titratable acidity) for all three harvest

campaigns. Blue dots refer to ForEl hybrids and green dots to ElFor ones. The red arrows indicate the Fortune mandarin parent and the orange arrows the Ellendale tangor parent

effect, diploid ForEl hybrids would have higher sugar and acid contents since their female parent Fortune has higher sugar and acid contents than Ellendale tangor. However, no significant differences were found between the two diploid populations. The hypothesis that allelic dosage affects the phenotype is consequently the most plausible.

A few studies have examined the phenotype variation of polyploid hybrid plants originating from reciprocal crosses but none in Citrus. However, several studies of polyploid crops addressed the question of the role of allele doses in gene expression. The studies agreed that most of the changes in gene expression were dose dependent. Dosage dependency has already been demonstrated in potato (Flipse et al. 1996; Stupar et al. 2007), maize (Guo et al. 1996; Auger et al. 2005; Riddle et al. 2010; Yao et al. 2011), Arabidopsis (Wang et al. 2006; Pignatta et al. 2010), sunflower (Church and Spaulding 2009) and wheat (Wickramasinghe and Miura 2003). As quantitative traits are controlled by many genes, the alleles involved in their expression should display a semi-dominant pattern (Mackay 1995) and thus exhibit dosage effects (Birchler and Auger 2013). Phenotypes should therefore be influenced by genome dosage (Birchler and Auger 2013). Some authors investigated gene expression using reciprocal hybrids. An examination of the genomic dosage effects on heterosis in reciprocal diploid and triploid hybrids of maize by Yao et al. (2013) showed huge significant differences between triploid hybrids whereas diploid hybrids were relatively similar (Yao et al. 2013). These authors thus excluded a parent-of-origin impact and instead concluded on a genomic dosage effect (Yao et al. 2013). Several studies conducted in the same ploidy level in maize (Guo et al. 2004; Stupar and Springer 2006) and Arabidopsis (Vuylsteke et al. 2005) also concluded on no or very little parental effect on gene expression.

\section{The effect of ploidy level on phenotypic variation}

Several significant differences due to the effect of ploidy level were observed in all the characters studied in almost all ForEl and ElFor populations. The transition from the diploid to triploid state had a significant impact neither on fruit weight or E/ A ratio of ForEl hybrids, nor on the titratable acidity of ElFor fruits. However, triploid hybrids exhibited significantly higher juice weight, higher sugar content and juice percentage than diploids. Results concerning the three other characters examined (average fruit weight, titratable acidity and E/A ratio) presented some significant differences but in only one population and harvesting campaign. We would at least have expected significant results concerning the average fruit weight since previous studies reported bigger tetraploid fruits than diploids (Cameron and Frost 1968; Jaskani et al. 2002). However, in contrast to tetraploids which generally contain many seeds, triploids are seedless and, as revealed by irradiated mutant analysis, seedless mutant fruits are significantly 
Fig. 5 Barplots comparing diploid and triploid ForEl on the one hand and diploid and triploid ElFor on the other, for all three harvesting campaigns. Red asterisks indicate significant ttests at the 0.05 level. a Average fruit weight. b Average juice weight. c: Sugar content. d Titratable acidity. e E/A ratio. $\mathbf{f}$ Juice percentage
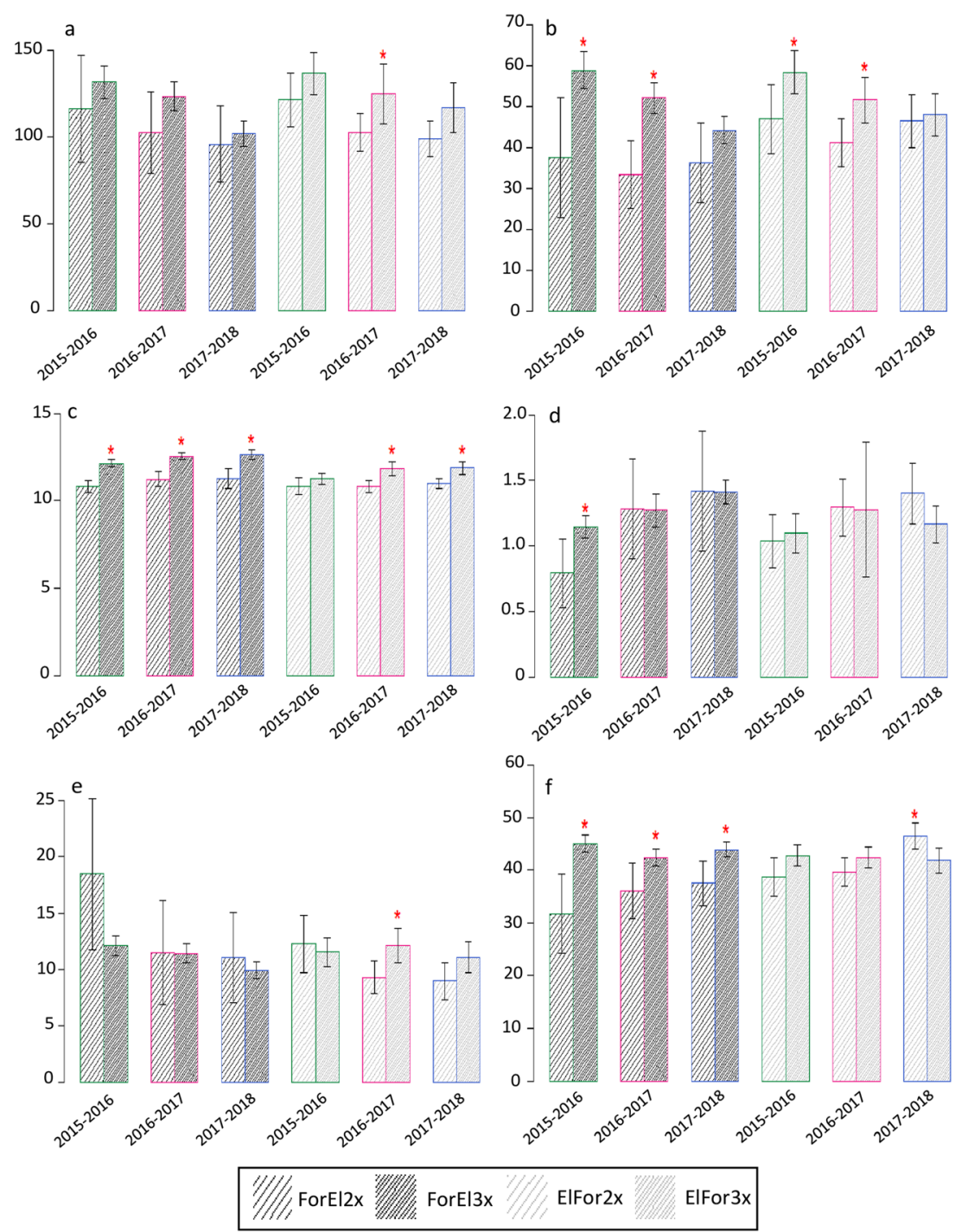

smaller than the original type (Goldenberg et al. 2014). The same relation between fruit size and seed content has also been observed in grape where it was linked to over production of gibberellic acid, which promotes fruit growth, in seedy fruits (Casanova et al. 2009). It can thus be assumed that other particularities of triploid plants (such as the greater cell size) can offset the lower cell division rate generally associated with gibberellic acid deficiency. In triploid breeding, this should be an advantage over mutation breeding for the development of new seedless mandarin cultivars to match market demand with respect to fruit size.

To our knowledge, the few studies which addressed the effect of the ploidy effect on phenotypic variation in citrus fruits (Cameron and Frost 1968; Jaskani et al. 2002) concerned diploid versus their doubled-diploid lines. To date, no study has examined the effect of the ploidy level in diploid and triploid hybrid populations originating from reciprocal crosses. Jaskani et al. (2002) compared diploid and tetraploid 'Kinnow' mandarins and showed that the tetraploids yielded significantly heavier fruits with a bigger diameter and a thicker rind skin than diploid mandarins. Their results are consistent with those of Cameron and Frost (1968) for different doubled-diploid citrus. An agronomic and genetic study on apples (Ramos-Cabrer et al. 2007) showed that triploid cultivars produced $15 \%$ heavier fruits than diploid cultivars. It has also been demonstrated that banana yield is affected by the ploidy level (Vuylsteke et al. 1993; Vandenhout et al. 1995). When triploid plantain bananas are crossed with diploid genotypes, diploid, triploid and tetraploid progenies are produced. While the tetraploids are the most promising due to their high yield (Vuylsteke et al. 1993), some parental combinations of triploid bananas were bigger and heavier (Vandenhout et al. 1995). Davis et al. (2013) compared six inbred lines of watermelon with their induced autotetraploids and autotriploids and found that autotriploid fruits were, in general, heavier and had bigger diameters than diploid and autotetraploid fruits. An impact of the ploidy level on the size and skin of kiwifruits has also been reported; colchicine- 
induced tetraploids had significantly thicker skins and were 50 to $60 \%$ bigger than diploids (Wu et al. 2013). All these results regarding the weight, width and thickness of fruits are in complete agreement with the general observation that cell size as well as organ thickness is positively correlated with the ploidy level (Smith et al. 2003; Stupar et al. 2007). Induced chromosome doubling in 'Thérèse Bugnet' rose increased leaf thickness (Kermani et al. 2003), and polyploid Dactylis glomerata presented significantly bigger stomatal cells (Bretagnolle and Lumaret 1995). Beyaz et al. (2013) demonstrated that tetraploid sugar beet had bigger but fewer cells than diploid genotypes, which has been reported to compensate for the reduced number of cells in polyploid genotypes (Doonan 2000; Inzé and De Veylder 2006).

According to several studies, variations in sugar content according to the ploidy level appear to be crop-dependent, but the relation is generally negative rather than positive. In citrus, total soluble solids (TSS) were lower in tetraploid mandarins than in diploid ones (Jaskani et al. 2002). Similar observations were reported for kiwifruits (Wu et al. 2013) and sugar beet (Beyaz et al. 2013). However, Davis et al. (2013) reported a positive correlation between the ploidy level and the sugar content in watermelons, although they pointed to a family $\times$ ploidy interaction which probably affected the increase in sugar content in polyploid genotypes.

Sugars are directly synthesized from sucrose, which is itself produced by photosynthesis in mature leaves (Smith et al. 2009). Numerous studies have shown that ploidy level increases leaf thickness, mesophyll cell volume (Barrett 1974; Byrne et al. 1981; Molin et al. 1982; Romero-Aranda 1997) and the length and width of stomata guard cells (Jones et al. 2007; Yuan et al. 2009; Ye et al. 2010; Padoan et al. 2013), but decreases stomata density (Yuan et al. 2009; Ye et al. 2010; Padoan et al. 2013). Stomata cells play a key role in photosynthetic activity as they allow carbon dioxide to reach mesophyll chloroplasts (Padoan et al. 2013). Although the photosynthetic rate per cell was reported to be associated with the amount of DNA per cell (Warner and Edwards 1993), photosynthetic rates were found to be negatively impacted by the increase of mesophyll cell volume (El-Sharkawy and Hesketh 1965; Wilson and Cooper 1970; Nobel et al. 1975; RomeroAranda 1997), which would cause internal resistance to carbon dioxide diffusion (Romero-Aranda 1997). Therefore, photosynthetic activity in diploid plants would logically be more efficient than in tetraploids and hence produce more sugar. However, in the present work, sugar contents were significantly higher in triploid than in diploid hybrids. This result suggests that triploids presented an equilibrium between stomata density, mesophyll area and in the amounts of photosynthetic enzymes which increase with ploidy level (Joseph et al. 1981; Molin et al. 1982; Leech et al. 1985) with the result that triploid photosynthesis outperforms that of diploid hybrids and sugar contents are consequently higher.

\section{Interest of triploid mandarins}

Although ploidy level can negatively affect some aspects of fruit quality, including thicker segments, trees displaying higher number of thorns, a lower productivity as well as a longer juvenile phase (Cameron and Frost 1968), not all polyploid citrus varieties are affected. Generating large numbers of hybrids, to be able to select elite triploid lines without these drawbacks, is likely to minimize these negative impacts. Besides being seedless, the main advantage of triploid mandarin hybrids is the better phenotypic results, regarding the evaluated quality-trait, than those of their diploid version, even though not all the statistical tests were significant. Compared to diploids, triploid fruits were heavier and contained more juice whose sugar content was higher. The results we obtained concerning the acidity level were not conclusive. Nonetheless, triploid ForEl and ElFor fruits exhibited high average values of the maturity index parameters. Sugar content and acidity level are main indicators of citrus fruit flavour and taste, and the ratio between them comprises the maturity index, which is widely used to choose the harvest period for marketable fruits. As stated by Lado et al. (2014), the sugar/acid ratio varies with the region, species and variety. To be accepted in the European market, the minimum threshold is 7.5 for mandarin varieties and their hybrids (EU 2013). The majority of both our triploid and diploid hybrids respect the European sugar/acid regulation. Triploid mandarins would be expected to be preferred by consumers looking for big juicy seedless fruits with a good balance between sugar and acidity levels. These triploid fruits would arrive on the market in January and continue until April. This is a period that corresponds to the end of the clementine season. Triploid mandarins would therefore complete the season for small citrus fruits thanks to their late maturing and production.

\section{Conclusion}

The aim of our study was to evaluate the effect of the cross direction and ploidy level on variations in some fruit quality characters. We phenotyped reciprocal diploid and triploid hybrids of mandarins between Fortune mandarin and Ellendale tangor over three harvest campaigns. Triploid ForEl mandarins were found to have significantly higher acidity levels and sugar contents than triploid ElFor hybrids. The observed differences between triploid ForEl and ElFor hybrids were consistent with a maternal effect based on the variations between the two parents. The ploidy level also positively affected juice weight, juice percentage and sugar content in the triploid fruits. A genomic dosage effect in which the female parent contributes two genomic doses is the most likely explanation for the variations we observed.

These innovative results will help optimize selection schemes for triploid crops, especially citrus fruits. Indeed, the phenotypic value of the parent producing the diploid 
gametes appears to be essential to drive the average value of the triploid progeny for several traits. Further investigations should focus on genomic expression and on identifying the origin of the $2 \mathrm{n}$ gametes for a deeper understanding and modelling of their involvement in phenotypic variation.

Author's contributions YF and PO designed the study. JCE provided phenotypic data. DA analysed the data. DA and PO wrote the manuscript.

Funding information This work received financial support from the European Regional Development Fund under the framework PO FEDER-FSE Corse 2014-2020 number 247SAEUFEDER1A, project called Innov'Agrumes (ARR-18/517 CE, synergy number: CO 0009083). The Collectivité de Corse provided the grant of Dalel Ahmed (number ARR-15.036680.SR).

\section{Compliance with ethical standards}

Conflict of interest The authors declare that they have no conflict of interest.

Data archiving statement All relevant data are within the paper and supplementary material.

Open Access This article is licensed under a Creative Commons Attribution 4.0 International License, which permits use, sharing, adaptation, distribution and reproduction in any medium or format, as long as you give appropriate credit to the original author(s) and the source, provide a link to the Creative Commons licence, and indicate if changes were made. The images or other third party material in this article are included in the article's Creative Commons licence, unless indicated otherwise in a credit line to the material. If material is not included in the article's Creative Commons licence and your intended use is not permitted by statutory regulation or exceeds the permitted use, you will need to obtain permission directly from the copyright holder. To view a copy of this licence, visit http://creativecommons.org/licenses/by/4.0/.

\section{References}

Abouzari A, Nezhad NM (2016) The investigation of citrus fruit quality. Popular Characteristic and Breeding. Acta Univ Agric Silvic Mendelianae Brun 64:725-740. https://doi.org/10.11118/ actaun201664030725

Aleza P, Cuenca J, Juárez J et al (2010a) 'Garbí' mandarin: a new latematuring triploid hybrid. HortScience 45:139-141

Aleza P, Juárez J, Cuenca J, Ollitrault P, Navarro L (2010b) Recovery of citrus triploid hybrids by embryo rescue and flow cytometry from $2 \mathrm{x}$ $\times 2 x$ sexual hybridisation and its application to extensive breeding programs. Plant Cell Rep 29:1023-1034. https://doi.org/10.1007/ S00299-010-0888-7

Aleza P, Froelicher Y, Schwarz S, Agustí M, Hernández M, Juárez J, Luro F, Morillon R, Navarro L, Ollitrault P (2011) Tetraploidization events by chromosome doubling of nucellar cells are frequent in apomictic citrus and are dependent on genotype and environment. Ann Bot 108:37-50. https://doi.org/10.1093/aob/mcr099

Aleza P, Juárez J, Cuenca J, Ollitrault P, Navarro L (2012a) Extensive citrus triploid hybrid production by $2 \mathrm{x} \times 4 \mathrm{x}$ sexual hybridizations and parent-effect on the length of the juvenile phase. Plant Cell Rep 31:1723-1735. https://doi.org/10.1007/s00299-012-1286-0
Aleza P, Juárez J, Hernández M, Ollitrault P, Navarro L (2012b) Implementation of extensive citrus triploid breeding programs based on $4 \mathrm{x} \times 2 \mathrm{x}$ sexual hybridisations. Tree Genet Genomes 8:12931306. https://doi.org/10.1007/s11295-012-0515-6

Aleza P, Cuenca J, Hernández M, Juárez J, Navarro L, Ollitrault P (2015) Genetic mapping of centromeres in the nine Citrus clementina chromosomes using half-tetrad analysis and recombination patterns in unreduced and haploid gametes. BMC Plant Biol 15:80. https://doi. org/10.1186/s12870-015-0464-y

Alquezar B, Rodrigo MJ, Zacarías L (2008) Regulation of carotenoid biosynthesis during fruit maturation in the red-fleshed orange mutant Cara Cara. Phytochemistry 69:1997-2007

Auger DL, Gray AD, Ream TS, Kato A, Coe EH Jr, Birchler JA (2005) Nonadditive gene expression in diploid and triploid hybrids of maize. Genetics 169:389-397. https://doi.org/10.1534/genetics. 104.032987

Barcaccia G, Tavoletti S, Falcinelli M, Veronesi F (1997) Environmental influences on the frequency and viability of meiotic and apomeiotic cells of a diploid mutant of alfalfa. Crop Sci 37:70. https://doi.org/ 10.2135/cropsci1997.0011183X003700010011x

Barrett HC (1974) Colchicine-induced polyploidy in citrus. Bot Gaz 135: $29-41$

Barry, Gmitter FG Jr, Chen C et al (2015) Investigating the parentage of 'Orri' and 'Fortune' mandarin hybrids. Acta Hortic:449-456. https://doi.org/10.17660/ActaHortic.2015.1065.55

Bartholomew ET, Sinclair WB (1943) Soluble constituents and buffer properties of orange juice. Plant Physiol 18:185-206. https://doi. org/10.1104/pp.18.2.185

Beyaz R, Alizadeh B, Gürel S et al (2013) Sugar beet (Beta vulgaris L.) growth at different ploidy levels. Caryologia 66:90-95. https://doi. org/10.1080/00087114.2013.787216

Bingham ET (1980) Maximizing heterozygosity in Autopolyploids. In: Lewis WH (ed) Polyploidy: biological relevance. Springer US, Boston, pp 471-489

Birchler JA, Auger DL (2013) Biological consequences of dosage dependent gene regulation in multicellular eukaryotes. In: Madame Curie Bioscience Database [Internet]. Austin (TX): Landes Bioscience. Available from: https://www.ncbi.nlm.nih.gov/books/NBK6042/

Blumwald E (2007) The determinants of sugar and acid content in citrus fruits and citrus fruit proteomics. https://www.citrusresearch.org/ wp-content/uploads/2007-Eduardo-Blumwald-Determinants-ofSugar-and-Acid.pdf. Accessed 19 July 2018

Bretagnolle F (2001) Pollen production and spontaneous polyploidization in diploid populations of Anthoxanthum alpinum. Biol J Linn Soc 72:241-247. https://doi.org/10.1006/bij1.2000.0489

Bretagnolle F, Lumaret R (1995) Bilateral polyploidization inDactylis glomerata L. subsp.lusitanica: occurrence, morphological and genetic characteristics of first polyploids. Euphytica 84:197-207. https:// doi.org/10.1007/BF01681812

Bretagnolle F, Thompson JD (1995) Gametes with the somatic chromosome number: mechanisms of their formation and role in the evolution of autopolyploid plants. New Phytol 129:1-22. https://doi.org/ 10.1111/j.1469-8137.1995.tb03005.x

Byrne MC, Nelson CJ, Randall DD (1981) Ploidy effects on anatomy and gas exchange of tall fescue leaves. Plant Physiol 68:891-893 https:// doi.org/10.1104/pp.68.4.891

Cai X, Xu SS (2007) Meiosis-driven genome variation in plants. Curr Genomics 8:151-161

Cameron C, Burnett B (1978) Use of sexual tetraploid seed parents for production of triploid citrus hybrids. Hortic Sci 13:167-169

Cameron JW, Frost HB (1968) Genetics, breeding, and nucellar embryony. In: Reuther W, Batchelor LD, Webber HJ (eds) The citrus industry. University of California, Riverside, pp 325-370

Carputo D, Frusciante L, Peloquin SJ (2003) The role of $2 \mathrm{n}$ gametes and endosperm balance number in the origin and evolution of polyploids in the tuber-bearing Solanums. Genetics 163:287-294 
Casanova L, Casanova R, Moret A, Agustí M (2009) The application of gibberellic acid increases berry size of "Emperatriz" seedless grape. Span J Agric Res 7:919. https://doi.org/10.5424/sjar/2009074-1105

Castellarin SD, Gambetta GA, Wada H, Shackel KA, Matthews MA (2011) Fruit ripening in Vitis vinifera: spatiotemporal relationships among turgor, sugar accumulation, and anthocyanin biosynthesis. J Exp Bot 62:4345-4354. https://doi.org/10.1093/jxb/err150

Church SA, Spaulding EJ (2009) Gene expression in a wild autopolyploid sunflower series. J Hered 100:491-495. https://doi.org/10. 1093/jhered/esp008

Cuenca J, Aleza P, Juárez J et al (2010) 'Safor' mandarin: a new Citrus mid-late triploid hybrid. HortScience 45:977-980

Cuenca J, Froelicher Y, Aleza P, Juárez J, Navarro L, Ollitrault P (2011) Multilocus half-tetrad analysis and centromere mapping in citrus: evidence of SDR mechanism for $2 \mathrm{n}$ megagametophyte production and partial chiasma interference in mandarin cv 'Fortune'. Heredity 107:462-470. https://doi.org/10.1038/hdy.2011.33

Cuenca J, Aleza P, Juárez J, García-Lor A, Froelicher Y, Navarro L, Ollitrault P (2015a) Maximum-likelihood method identifies meiotic restitution mechanism from heterozygosity transmission of centromeric loci: application in citrus. Sci Rep 5:1-11. https://doi.org/10. 1038/srep09897

Cuenca J, Aleza P, Juárez J et al (2015b) Two new IVIA triploid mandarin hybrids: 'Alborea' and 'Albir'. Acta Hortic:209-214. https://doi. org/10.17660/ActaHortic.2015.1065.22

Davis AR, Webber CL, Liu W et al (2013) Watermelon quality traits as affected by ploidy. HortScience 48:1113-1118

Dewitte A, Laere K, Huylenbroeck J (2012) Use of 2n gametes in plant breeding. Plant breeding, Dr. Ibrokhim Abdurakhmonov (ed.), ISBN 978-953-307-932-5

Doonan J (2000) Social controls on cell proliferation in plants. Curr Opin Plant Biol 3:482-487. https://doi.org/10.1016/S1369-5266(00) 00117-5

Echeverria E, Valich J (1988) Carbohydrate and enzyme distribution in protoplasts from Valencia orange juice sacs. Phytochemistry 27:7376. https://doi.org/10.1016/0031-9422(88)80593-4

El-Sharkawy M, Hesketh J (1965) Photosynthesis among species in relation to characteristics of leaf anatomy and $\mathrm{CO} 2$ diffusion resistances. Crop Sci:517-521

Esen A, Soost RK (1971) Unexpected triploids in citrus: their origin, identification, and possible use. J Hered 62:329-333. https://doi. org/10.1093/oxfordjournals.jhered.a108186

Esen A, Soost RK (1973a) Seed development in citrus with special reference to 2x X 4x crosses. Am J Bot 60:448-462. https://doi.org/10. 1002/j.1537-2197.1973.tb05945.x

Esen A, Soost RK (1973b) Precocious development and germination of spontaneous triploid seeds in citrus. J Hered 64:147-154. https://doi. org/10.1093/oxfordjournals.jhered.a108373

Esen A, Soost RK, Geraci G (1979) Genetic evidence for the origin of diploid megagametophytes in citrus. J Hered 70:5-8. https://doi.org/ 10.1093/oxfordjournals.jhered.a109188

EU (2013) Norme de commercialisation applicable aux agrumes. https:// www.ble.de/SharedDocs/Downloads/FR/ObstUndGemuese/ Agrumes.pdf?_blob=publicationFile\&v=1. Accessed 8 October 2018

EU (2017) Norme CEE-ONU FFV-14 concernant la commercialisation et le contrôle de la qualité commerciale des agrumes. https://www. unece.org/fileadmin/DAM/trade/agr/standard/standard/fresh/FFVStd/French/14 CitrusFruit.pdf. Accessed 8 October 2018

FAOSTAT (2017) Citrus Fruit, Fresh and processed - Statistical Bulletin. http://www.fao.org/economic/est/est-commodities/citrus-fruit/en/. Accessed 14 June 2019

FAOSTAT (2019) Crops. http://www.fao.org/faostat/en/\#data/QC/ visualize. Accessed 14 June 2019

Flipse E, Visser RGF, Jacobsen E, Visser RGF (1996) The dosage effect of the wildtype GBSS allele is linear for GBSS activity but not for amylose content: absence of amylose has a distinct influence on the physico-chemical properties of starch. Theor Appl Genet 92:121-127

Froelicher Y, Mouhaya W, Bassene J-B et al (2011) New universal mitochondrial PCR markers reveal new information on maternal citrus phylogeny. Tree Genet Genomes 7:49-61. https://doi.org/10.1007/ s11295-010-0314-x

Frost HB, Soost RK (1968) Seed reproduction, development of gametes and embryos. In: Reuther W, Batchelor LD, Webber HB (eds) The citrus industry, vol 2. University of California, Barkley, pp 290-324

Furr JR (1964) New tangerines for the desert. California Citrograph 49:266-276

Gallais A (2003) Quantitative genetics and breeding methods in autopolyploid plants. Quae Editions, Paris

Garcia-Lor A, Luro F, Ollitrault P, Navarro L (2015) Genetic diversity and population structure analysis of mandarin germplasm by nuclear, chloroplastic and mitochondrial markers. Tree Genet Genomes 11:1-15. https://doi.org/10.1007/s11295-015-0951-1

Geraci G, Esen A, Soost RK (1975) Triploid progenies of citrus cultivars from $2 \mathrm{x} \times 2 \mathrm{x}$ crosses. J Hered 66:177-178 https://doi.org/10.1093/ oxfordjournals.jhered.a108607

Goff SA, Klee HJ (2006) Plant volatile compounds: sensory cues for health and nutritional value? Science 311:815-819. https://doi.org/ 10.1126/science. 1112614

Goldenberg L, Yaniv Y, Kaplunov T, Doron-Faigenboim A, Porat R, Carmi N (2014) Genetic diversity among mandarins in fruitquality traits. J Agric Food Chem 62:4938-4946. https://doi.org/ 10.1021/jf5002414

Goldenberg L, Yaniv Y, Kaplunov T, Doron-Faigenboim A, Carmi N, Porat R (2015) Diversity in sensory quality and determining factors influencing mandarin flavor liking. J Food Sci 80:S418-S425. https://doi.org/10.1111/1750-3841.12742

Goldenberg L, Yaniv Y, Porat R, Carmi N (2018) Mandarin fruit quality: a review: mandarin fruit quality. J Sci Food Agric 98:18-26 https:// doi.org/10.1002/jsfa.8495

Gomez V, Rodriguez-Garay B, Barba Gonzalez R (2012) Meiotic restitution mechanisms involved in the formation of $2 \mathrm{n}$ pollen in Agave tequilana weber and Agave angustifolia haw. SpringerPlus 1:17. https://doi.org/10.1186/2193-1801-1-17

Grosser JW, Gmitter FG (2011) Protoplast fusion for production of tetraploids and triploids: applications for scion and rootstock breeding in citrus. Plant Cell Tissue Organ Cult 104:343-357. https://doi.org/10. 1007/s11240-010-9823-4

Guo M, Davis D, Birchler JA (1996) Dosage effects on gene expression in a maize ploidy series. Genetics 142:1349-1355

Guo M, Rupe MA, Zinselmeier C, Habben J, Bowen BA, Smith OS (2004) Allelic variation of gene expression in maize hybrids. Plant Cell 16:1707-1716. https://doi.org/10.1105/tpc.022087

Handaji N, Hamid B, Najat A, Hassan B (2018) AYA and HANA: new seedless Mandarin's triploid hybrids selected in Morocco. Biotechnol J Int 21(1):1-9

Hodgson RW (1967) Horticultural varieties of citrus. In: Reuther W, Webber HJ, Batchelor LD (eds) The Citrus industry V.1. University of California Press, Berkeley, pp 431-591

Honsho C, Yamamura E, Tsuruta K et al (2012) Unreduced 2n pollen production in 'Nishiuchi Konatsu' Hyuganatsu as inferred by pollen characteristics and progeny ploidy level. J Jpn Soc Hortic Sci 81:19 26. https://doi.org/10.2503/jjshs1.81.19

Honsho C, Sakata A, Tanaka H, Ishimura S, Tetsumura T (2016) Singlepollen genotyping to estimate mode of unreduced pollen formation in Citrus tamurana cv. Nishiuchi Konatsu. Plant Reprod 29:189197. https://doi.org/10.1007/s00497-016-0277-7

Husson F, Josse J, Le S, Mazet J (2016) FactoMineR: multivariate exploratory data analysis and data mining with $\mathrm{R}$. R package version 1.32. http://CRAN.R-project.org/package=FactoMineR

Inzé D, De Veylder L (2006) Cell cycle regulation in plant development. Annu Rev Genet 40:77-105. https://doi.org/10.1146/annurev.genet. 40.110405 .090431 
Iwamasa M, Nito N, Ling JT (1988) Proceedings of 6th international citrus congress. International Society of Citriculture. Intra and intergeneric hybridization in the orange subfamily, Auranthioideae, Balaban, PA, pp 123-130

Iwanaga M, Freyre R, Orjeda G (1991) Use of Ipomoea trifida (HBK.) G. Don germ plasm for sweet potato improvement. 1. Development of synthetic hexaploids of I. trifida by ploidy-level manipulations. Genome 34:201-208. https://doi.org/10.1139/g91-032

Jaskani MJ, Khan MM, Khan IA (2002) Growth, morphology and fruit comparison of diploid and tetraploid 'Kinnow' mandarin. Pak J Agric Sci 39:126-128

Jones KD, Reed SM, Rinehart TA (2007) Analysis of ploidy level and its effects on guard cell length, pollen diameter, and fertility in hydrangea macrophylla. HortScience 42:483-488. https://doi.org/10. 21273/HORTSCI.42.3.483

Joseph MC, Randall DD, Nelson CJ (1981) Photosynthesis in polyploid tall fescue: II. Photosynthesis and ribulose-1, 5-bisphosphate carboxylase of polyploid tall fescue. Plant Physiol 68:894-898. https://doi.org/10.1104/pp.68.4.894

Kassambara A, Mundt F (2017) Factoextra: extract and visualize the results of multivariate data analyses. $\mathrm{R}$ package version 1.0.5. https://CRAN.R-project.org/package=factoextra

Kermani MJ, Sarasan V, Roberts AV, Yokoya K, Wentworth J, Sieber VK (2003) Oryzalin-induced chromosome doubling in Rosa and its effect on plant morphology and pollen viability. TAG Theor Appl Genet 107:1195-1200. https://doi.org/10.1007/s00122-003-1374-1

Krug CA (1943) Chromosome numbers in the subfamily Aurantioideae with special reference to the genus citrus. Bot Gaz 104:602-611. https://doi.org/10.1086/335173

Lado J, Rodrigo MJ, Zacarías L (2014) Maturity indicators and citrus fruit quality. Stewart Postharvest Rev 10(2):1-6

Leech RM, Leese BM, Jellings AJ (1985) Variation in cellular ribulose-1, 5-bisphosphate-carboxylase content in leaves of Triticum genotypes at three levels of ploidy. Planta 166:259-263. https://doi.org/10. 1007/BF00397357

Liesebach H, Ulrich K, Ewald D (2015) FDR and SDR processes in meiosis and diploid gamete formation in poplars (Populus L.) detected by centromere-associated microsatellite markers. Tree Genet Genomes 11:801

Liu J, Li J, Liu H, Fan SH, Singh S, Zhou XR, Hu ZY, Wang HZ, Hua W (2018) Genome-wide screening and analysis of imprinted genes in rapeseed (Brassica napus L.) endosperm. DNA Res 25:629-640. https://doi.org/10.1093/dnares/dsy030

Luro F, Maddy F, Jacquemond C et al (2004) Identification and evaluation of diplogyny in clementine (Citrus clementina) for use in breeding. Acta Hortic 663:841-848

Lyrene PM, Vorsa N, Ballington JR (2003) Polyploidy and sexual polyploidization in the genus Vaccinium. Euphytica 133:27-36. https://doi.org/10.1023/A:1025608408727

Maceira NO, Haan AD, Lumaret R et al (1992) Production of 2n gametes in diploid subspecies of Dactylis glomerata L. 1. Occurrence and frequency of $2 \mathrm{n}$ pollen. Ann Bot 69:335-343. https://doi.org/10. 1093/oxfordjournals.aob.a088350

Mackay TF (1995) The genetic basis of quantitative variation: numbers of sensory bristles of Drosophila melanogaster as a model system. Trends Genet 11:464-470

Mason AS, Nelson MN, Yan G, Cowling WA (2011) Production of viable male unreduced gametes in Brassica interspecific hybrids is genotype specific and stimulated by cold temperatures. BMC Plant Biol 11:103. https://doi.org/10.1186/1471-2229-11-103

Mendiburu AO, Peloquin SJ (1971) High yielding tetraploids from 4x-2x and 2x-2x matings. Am Pot J 48:300-301

Mendiburu AO, Peloquin SJ (1977a) The significance of $2 \mathrm{~N}$ gametes in potato breeding. Theor Appl Genet 49:53-61. https://doi.org/10. 1007/BF00275164
Mendiburu AO, Peloquin SJ (1977b) Bilateral sexual polyploidization in potatoes. Euphytica 26:573-583 https://doi.org/10.1007/BF00021683

Miyazaki T, Plotto A, Baldwin EA, Reyes-De-Corcuera JI, Gmitter FG Jr (2012) Aroma characterization of tangerine hybrids by gaschromatography-olfactometry and sensory evaluation. J Sci Food Agric 92:727-735

Mok DWS, Peloquin SJ, Tarn TR (1975) Cytology of potato triploids producing $2 \mathrm{~N}$ pollen. Am J Pot Res 52:171-174. https://doi.org/10. 1007/BF02838107

Molin WT, Meyers SP, Baer GR, Schrader LE (1982) Ploidy effects in isogenic populations of alfalfa : II. photosynthesis, chloroplast number, ribulose-1,5-Bisphosphate carboxylase, chlorophyll, and DNA in protoplasts. Plant Physiol 70:1710-1714. https://doi.org/10.1104/ pp.70.6.1710

Murata T (1977) Studies on the postharvest physiology and storage of citrus fruit. J Jpn Soc Hortic Sci 46(2):283-287

Navarro L, Juárez J, Aleza P, Pina JA (2003) Recovery of triploid seedless mandarin hybrids from $2 n \times 2 n$ and $2 n \times 4 n$ crosses by embryo rescue and flow cytometry. In: Vasil IK (ed) Plant biotechnology 2002 and beyond. Springer, Dordrecht, pp 514-544

Navarro L, Pablo A, José C et al (2015) The mandarin triploid breeding program in Spain. Acta Hortic:389-395. https://doi.org/10.17660/ ActaHortic.2015.1065.48

Nobel PS, Zaragoza LJ, Smith WK (1975) Relation between mesophyll surface area, photosynthetic rate, and illumination level during development for leaves of Plectranthus parviflorus Henckel 1. Plant Physiol 55:1067-1070

Ohnishi T, Sekine D, Kinoshita T (2014) Genomic imprinting in plants: what makes the functions of paternal and maternal genes different in endosperm formation? Adv Genet 86:1-25. https://doi.org/10.1016/ B978-0-12-800222-3.00001-2

Ollitrault P, Dambier D, Sudahono LF (1996) Somatic hybridisation in citrus : some new hybrid and alloplasmic plants. Proc Int Soc Citric 2:907-912

Ollitrault P, Jacquemond C, Dubois C, Luro F (2003) Citrus. In: Hamon P, Seguin M, Perrier X, Glaszmann JC (eds) Genetic diversity of cultivated tropical plants. CIRAD, Montpellier, pp 193-217

Ollitrault P, Dambier D, Luro F, Froelicher Y (2008) Ploidy manipulation for breeding seedless triploid citrus. Plant Breed Rev 20:323-354

Ortiz R (1997) Occurrence and inheritance of 2nPollen in Musa. Ann Bot 79:449-453. https://doi.org/10.1006/anbo.1996.0367

Otto SP, Whitton J (2000) Polyploid incidence and evolution. Annu Rev Genet 34:401-437. https://doi.org/10.1146/annurev.genet.34.1.401

Padoan D, Mossad A, Chiancone B et al (2013) Ploidy levels in Citrus clementine affects leaf morphology, stomatal density and water content. Theor Exp Plant Physiol 25:283-290. https://doi.org/10.1590/ S2197-00252013000400006

Peloquin SJ, Yerk GL, Werner JE, Darmo E (1989) Potato breeding with haploids and 2 n gametes. Genome 31:1000-1004. https://doi.org/ 10.1139/g89-174

Pignatta D, Dilkes BP, Yoo S-Y, Henry IM, Madlung A, Doerge RW, Jeffrey Chen Z, Comai L (2010) Differential sensitivity of the Arabidopsis thaliana transcriptome and enhancers to the effects of genome doubling. New Phytol 186:194-206. https://doi.org/10. 1111/j.1469-8137.2010.03198.x

Ramanna MS, Jacobsen E (2003) Relevance of sexual polyploidization for crop improvement - a review. Euphytica 133:3-18

Ramos-Cabrer AM, Díaz-Hernández MB, Pereira-Lorenzo S (2007) Morphology and microsatellites in Spanish apple collections. J Hortic Sci Biotechnol 82:257-265. https://doi.org/10.1080/ 14620316.2007 .11512227

Ramsey J (2007) Unreduced gametes and neopolyploids in natural populations of Achillea borealis (Asteraceae). Heredity 98:143-150. https://doi.org/10.1038/sj.hdy.6800912

Ramsey J, Schemske DW (2002) Neopolyploidy in flowering plants. Annu Rev Ecol Syst 33:589-639. https://doi.org/10.1146/annurev. ecolsys.33.010802.150437 
Rapisarda P, Bellomo SE, Fabroni S, Russo G (2008) Juice quality of two new mandarin-like hybrids ( Citrus clementina Hort. ex Tan x Citrus sinensis L. Osbeck) containing Anthocyanins. J Agric Food Chem 56:2074-2078. https://doi.org/10.1021/jf072616e

Rhoades MM, Dempsey E (1966) Induction of chromosome doubling at meiosis by the elongate gene in maize. Genetics 54:505-522

Riddle NC, Jiang H, An L, Doerge RW, Birchler JA (2010) Gene expression analysis at the intersection of ploidy and hybridity in maize. Theor Appl Genet 120:341-353. https://doi.org/10.1007/s00122-009-1113-3

Romero-Aranda R (1997) Leaf characteristics and net gas exchange of diploid and Autotetraploid citrus. Ann Bot 79:153-160. https://doi. org/10.1006/anbo.1996.0326

Rouiss H, Cuenca J, Navarro L et al (2017a) Tetraploid citrus progenies arising from FDR and SDR unreduced pollen in $4 \times$ X 2x hybridizations. Tree Genet Genomes 13. https://oi.org/10.1007/s11295-016-1094-8

Rouiss H, Cuenca J, Navarro L et al (2017b) Unreduced Megagametophyte production in lemon occurs via three meiotic mechanisms, predominantly second-division restitution. Front Plant Sci 8. https://doi.org/10.3389/fpls.2017.01211

Russo G, Recupero GR, Recupero S, Paolo DP (2015) 'Sweet sicily' and 'early sicily', two new triploids from the program of CRA-Research Centre of Citriculture and Mediterranen crops. Acta Hortic 1065: 215-221. https://doi.org/10.17660/ActaHortic.2015.1065.23

Schieberle P, Mestres M, Buettner A (2003) Characterization of aroma compounds in fresh and processed mandarin oranges. In: Cadwallader KR, Weenen $\mathrm{H}$ (eds) Freshness and shelf life of foods. Amer Chemical Soc, Washington, pp 162-174

Smith RR, Taylor NL, Bowley SR (1985) Red clover. In: Taylor NL (ed) Clover Science and Technology, vol 25. Amer. Soc. Agron. Monograph, Madison, pp 457-470

Smith KF, McFarlane NM, Croft VM et al (2003) The effects of ploidy and seed mass on the emergence and early vigour of perennial ryegrass (Lolium perenne L.) cultivars. Aust J Exp Agric 43:481. https://doi.org/10.1071/EA01130

Smith AM, Coupland G, Dolan L et al (2009) Plant biology. Garland Science, New York

Soost RK (1987) Breeding citrus-genetics and nucellar embryony. In: Abbott AJ, Atkin RK (eds) Improving vegetatively propagated crops. Academic Press, London, pp 83-110

Spiegel-Roy P, Goldschmidt EE (1996) Biology of citrus. Cambridge University Press, Cambridge ISBN 0-521-33321-0

Starrantino A, Recupero G (1981) Citrus hybrids obtained in vitro from $2 \mathrm{X}$ females X 4X males. Proc Int Soc Citricult 1:31-32

Stebbins GL (1947) Types of polyploids: their classification and significance. Adv Genet 1:403-429

Storme ND, Geelen D (2013) Sexual polyploidization in plants - cytological mechanisms and molecular regulation. New Phytol 198: 670-684. https://doi.org/10.1111/nph.12184

Stupar RM, Springer NM (2006) Cis-transcriptional variation in maize inbred lines B73 and Mo17 leads to additive expression patterns in the F1 hybrid. Genetics 173:2199-2210. https://doi.org/10.1534/ genetics.106.060699

Stupar RM, Bhaskar PB, Yandell BS, Rensink WA, Hart AL, Ouyang S, Veilleux RE, Busse JS, Erhardt RJ, Buell CR, Jiang J (2007) Phenotypic and Transcriptomic changes associated with potato Autopolyploidization. Genetics 176:2055-2067. https://doi.org/10. 1534/genetics.107.074286

Tietel Z, Plotto A, Fallik E, Lewinsohn E, Porat R (2011) Taste and aroma of fresh and stored mandarins. J Sci Food Agric 91:14-23. https:// doi.org/10.1002/jsfa.4146

Vandenhout H, Ortiz R, Vuylsteke D, Swennen R, Bai KV (1995) Effect of ploidy on stomatal and other quantitative traits in plantain and banana hybrids. Euphytica 83:117-122. https://doi.org/10.1007/ BF01678038

Veronesi F, Mariani A, Bingham ET (1986) Unreduced gametes in diploid Medicago and their importance in alfalfa breeding. Theor Appl Genet 72:37-41. https://doi.org/10.1007/BF00261451

Vuylsteke DR, Swennen RL, Ortiz R (1993) Development and performance of black Sigatoka-resistant tetraploid hybrids of plantain (Musa spp., AAB group). Euphytica 65:33-42

Vuylsteke M, van Eeuwijk F, Van Hummelen P et al (2005) Genetic analysis of variation in gene expression in Arabidopsis thaliana. Genetics 171:1267-1275. https://doi.org/10.1534/genetics.105.041509

Wang J, Tian L, Lee H-S, Wei NE, Jiang H, Watson B, Madlung A, Osborn TC, Doerge RW, Comai L, Chen ZJ (2006) Genomewide nonadditive gene regulation in Arabidopsis allotetraploids. Genetics 172:507-517. https://doi.org/10.1534/genetics.105.047894

Warner D, Edwards G (1993) Effects of polyploidy on photosynthesis. Photosynth Res 35:135-147. https://doi.org/10.1007/BF00014744

Warnes GR, Bolker B, Bonebakker L et al (2016) Gplots: various R programming tools for plotting data. $\mathrm{R}$ package version 3.0.1. https://CRAN.R-project.org/package=gplots

Wickramasinghe HAM, Miura H (2003) Gene dosage effect of the wheat Wx alleles and their interaction on amylose synthesis in the endosperm. Euphytica 132:303-310

Wilson D, Cooper JP (1970) Effect of selection for mesophyll cell size on growth and assimilation in Lolium perenne L. New Phytol 69:233-245

Wu J-H, Ferguson AR, Murray BG et al (2013) Fruit quality in induced polyploids of Actinidia chinensis. HortScience 48:701-707

Xie KD, Wang XP, Biswas MK, Liang WJ, Xu Q, Grosser JW, Guo WW (2014) 2 n megagametophyte formed via SDR contributes to tetraploidization in polyembryonic 'Nadorcott' tangor crossed by citrus allotetraploids. Plant Cell Rep 33:1641-1650

Xie KD, Xia QM, Wang XP et al (2015) Cytogenetic and SSR marker evidence of mixed disomic, tetrasomic and intermediate inheritance in a citrus allotetraploid somatic hybrid between 'Nova' tangelo and 'HB' pummelo. Tree Genet Genomes 11:112

Xie KD, Xia QM, Peng J et al (2019a) Mechanism underlying 2n male and female gamete formation in lemon via cytological and molecular marker analysis. Plant Biotechnol Rep 13:141-149

Xie KD, Yuan DY, Wang W et al (2019b) Citrus triploid recovery based on $2 \mathrm{x} \times 4 \mathrm{x}$ crosses via an optimized embryo rescue approach. Sci Hortic 252:104-109

Yao H, Kato A, Mooney B, Birchler JA (2011) Phenotypic and gene expression analyses of a ploidy series of maize inbred Oh43. Plant Mol Biol 75:237-251. https://doi.org/10.1007/s11103-010-9722-4

Yao H, Dogra Gray A, Auger DL, Birchler JA (2013) Genomic dosage effects on heterosis in triploid maize. Proc Natl Acad Sci U S A 110: 2665-2669. https://doi.org/10.1073/pnas. 1221966110

Ye YM, Tong J, Shi XP et al (2010) Morphological and cytological studies of diploid and colchicine-induced tetraploid lines of crape myrtle (Lagerstroemia indica L.). Sci Hortic 124:95-101. https:// doi.org/10.1016/j.scienta.2009.12.016

Yuan S, Liu Y, Fang Z et al (2009) Study on the relationship between the ploidy level of microspore-derived plants and the number of chloroplast in Stomatal guard cells in Brassica oleracea. Agric Sci China 8:939-946. https://doi.org/10.1016/S1671-2927(08)60298-9

Zlesak DC (2009) Pollen diameter and guard cell length as predictors of ploidy in diverse rose cultivars, species, and breeding lines. Floricult Ornamental Biotechnol 3:53-70

Publisher's note Springer Nature remains neutral with regard to jurisdictional claims in published maps and institutional affiliations. 